\title{
Student Understanding and Learning in Team Sports: Understanding through Game-Play Analysis
}

\begin{abstract}
By Zeineb Zerai*, Jean-Francis Gréhaigne ${ }^{ \pm} \&$ Paul Godbout
The purpose of this paper is three-fold: (a) to summarily examine the matters of team-sport subject-matter knowledge and student team-sport pedagogical content knowledge learning as they evolved in France since the 1960s, (b) to recall briefly the main constitutive elements of the Tactical-Decision Learning Model (T-DLM) and their ties with student understanding and learning, and (c) to illustrate the use configurations of play and effective play-spaces as tools for enhancing student learning. Through T-DLM, students are challenged to collectively plan action projects, implement them in game play situations, and conclude as to their level of success or failure, going through several iterations of the process until stabilization of their acquired knowledge. This learning process unfolds under the teacher's learned and facilitating guidance.
\end{abstract}

Keywords: T-DLM, team-sport understanding, debate-of-ideas, configuration of play, student-centered approach

\section{Introduction}

In 2005, Griffin and Butler stated that in contemporary physical education (PE) research, pedagogical theory had begun shifting from questions about the process/product paradigm to questions about the student's learning process. With regard to the teaching/learning of team sports, there appears to have been, since the late 1960s, two lines of theorization, one concerning the team-sport related content knowledge, and the other concerning students' or players' appropriation of that knowledge. Much has been written in the last three decades about teaching/ learning models. A substantial part of that literature has been published in Physical Education and Sport Pedagogy and in the Journal of Teaching in Physical Education. For various reasons, PE practices and theories developed in nonEnglish speaking countries have not always reached the Anglophone readership. A particular learning theory, constructivism, has significantly influenced the evolution of PE teaching practices in France, leading to the development of a teaching/ learning model in relation with decision making in team sports. In English, the model has been titled Tactical-Decision Learning Model (TDLM).

The use of a tactical approach as framework, along with the contribution of a constructivist and cognitivist perspective and their work on tactical knowledge in team sports has led researchers, in the context of school physical education, to put forward the T-DLM. From a pedagogical point of view, in order to draw student

\footnotetext{
*Assistant Professor, ISSEP Ksar Saïd de Tunis, Tunisia and GRIAPS, University of Bourgogne Franche-Comté, France.

${ }^{ \pm}$Professor, GRIAPS, University of Bourgogne Franche-Comté, France.

Professor, Laval University, Canada.
} 
attention to prototypic patterns of play, teachers may use data collected during or after game play. For instance, they can gather information from a debate-of-ideas set-up with various game forms and team sports. It may also be hypothesized that by studying these configurations of play, one will help students construct an operational image predictive of the way a given situation of play is likely to evolve. The help of new observation tools makes it possible to describe the dynamics of game-play. It seems that linking five criteria (EP-S field location; ball position and circulation; offensive effective play-space and defensive effective play-space positions; defense in block or in pursuit) provides an immediate representation of the opposition relationship.

\section{Team-Sport Subject-Matter Knowledge and its Appropriation by Students/ Players}

\section{Team-Sport Subject-Matter Knowledge}

In 1965, Teodorescu, from the University of Bucharest (Romania), published a paper in French discussing principles that ought to be considered in the study of common tactics in team sports and their relationship with teams' and players' tactical training. The paper reproduced a lecture presented at the 1965 Vichy Seminar titled "The planning of team sport teaching". That French publication from Teodorescu being no longer available, editors of the eJRIEPS decided to republish it for the benefit of interested readers (Teodorescu 2013). In this paper, Teodorescu's premise was that tactics was the most obvious common factor with regard to team sports. In his book on rugby, Deleplace (1966) developed at length team-sport knowledge that could be applied to invasion team-sport in general, particularly with regard to movements of players and the ball in relation to space and time. Beyond the analysis of sport-related fundamental features, the notion of modelling contributed also to the development of team-sport subject-matter knowledge. Discussing the complexity of situations of play in soccer, Menaut (1982) submitted that resorting to formal thinking seems to constitute a realistic enough model of tools used by players to organize reality and structure their tactical action (p. 38).

Through didactical transposition (Amade-Escot 2000), this subject-matter knowledge penetrated into PE teaching practices, under the form of Pedagogical Content Knowledge (PCK) (e.g., Gréhaigne et al. 1988, Gréhaigne and Guillon 1991).

\section{Student Knowledge-Learning in Team Sports}

Concerning students' learning of team-sport related PCK, the first research known on a game-based approach is, as far as we know, that of Mahlo (1969) (originally published in German in 1965). Malho studied game play phases and showed the complex character of "tactical action in play". He identified the following components of the sport-learning process (see Figure 1): 
- perception and analysis of game play (resulting into knowledge of the evolution of the setting);

- mental solution to the problem (involving knowledge of the likely evolution of the setting and the representation of some plan of action);

- motor skill solution to the problem (resulting into the practical solution).

Figure 1. The Phases of Game Play according to Mahlo (1969)

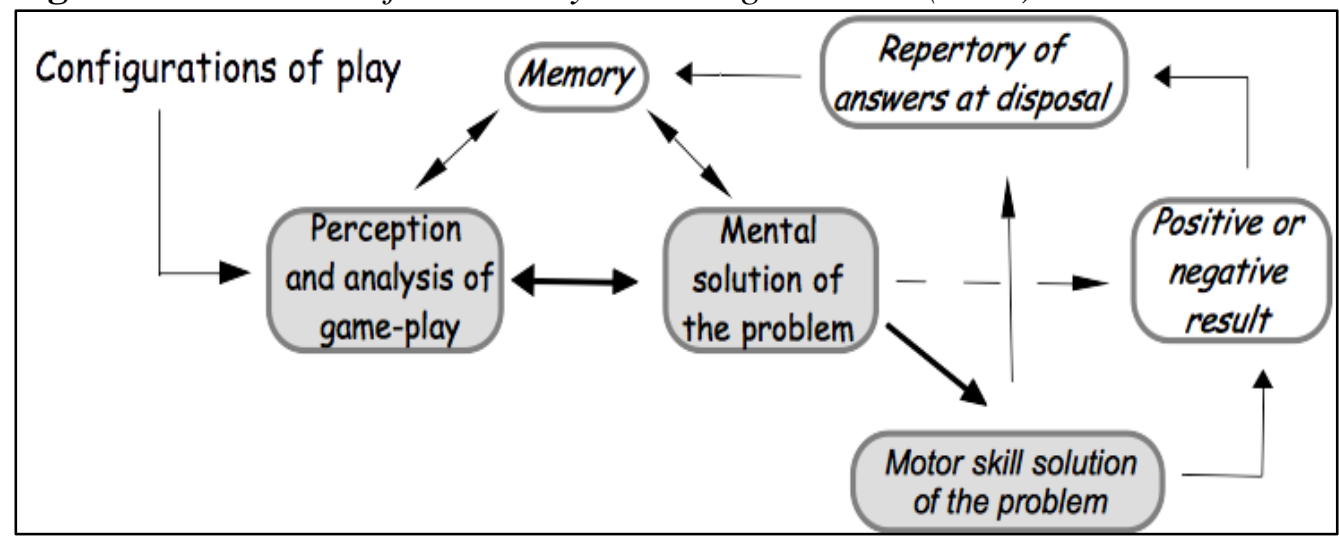

Mahlo had put forward the notion of knowledge and advance-organization in game play from cognitive and tactical aspects of the play. To gather information relative to this problem, he studied the answers of players and coaches from various levels of play, confronted to different configurations of play. Mahlo's work was a first step towards a tactical approach in team sport.

In September 1965, a Seminar involving some $140 \mathrm{PE}$ teacher educators was held in Vichy (France). The theme of the Seminar was "the planning of team sport teaching" and put forward a team-sport pedagogy as a tool for school PE (Vandevelde 2007). In the same line of thought and offered from 1964 to the 1980s by the FSGT (Fédération Sportive et Gymnique du Travail) [Sport and Gymnastic Federation for Workers], the Maurice Baquet teacher-training sessions were held in the context of summer camps for 6 to 12-year old children. They were intended for PE teachers' continuing education with regard to the teaching of numerous sport activities. The pedagogical approach was resolutely studentcentered and called for teachers' renewal of their practice. "Working in view of the emergence of 'sport for the child' means avoiding a pedagogy of sport-skill learning. ... The organization of the training session is the discovery of solutions rather than the appropriation of ready-made solutions" (translated from Mérand 1974, pp. 34, 37). As a follow-up to these training sessions, a series of 12 mementos CPS-FSGT (e.g., Marsenach and Druenne 1974) were published covering numerous team sports and systematically promoting the use small-sided games, a strategy advocated for rugby by Deleplace (1966) and by Frantz several years prior to the publication of his book on soccer (Frantz 1975). The table was set for the emergence of tactical-decision-models pedagogy. This approach postulated that the intervention of cognitive processes is decisive for the orientation and motor control of actions. It assumes that the presentation of 
significant perceptual clues and of rational tactical-choices principles plays a major role in the enacting of action, including the quality of execution (Bouthier 1984, p. $85)$.

A tactical-decision-models pedagogy offered the management of discussions, interactions and problem solving through debates of ideas (DoI) among students (Deriaz et al. 1998, Gréhaigne and Godbout 1998b), in view of a better understanding of game-play and true learnings.

In 1982, Bunker and Thorpe published their now classic paper on Teaching Game for Understanding. As a result, several game-based approaches (GBA), or game-centered approaches (GCA) (Harvey and Jarret 2014), started emerging in the English literature. Among them, one finds Sport Education (Siedentop 2002), Tactical Games approach (TGA) (Griffin et al. 1997), and Game Sense approach (GSA) (Light 2004). In France, based on the evolution of T-DMP (Bouthier 1988, Deleplace 1979, Gréhaigne 1989), a model for students' construction of tactical knowledge in team sport developed in the 1990s (Gréhaigne and Godbout 1995, Gréhaigne and Godbout 1998b, Gréhaigne et al. 1999, Gréhaigne et al. 2001). The model was eventually formally titled tactical-decision learning model (T-DLM) in the English literature by 2005 (Gréhaigne et al. 2005a, b).

In the student- and player-centered models mentioned above, a common characteristic is the use of student exchanges or discussion during the teaching/ learning process. Also, priority is given to game play in small-sided-game set-ups, along with tactical learning, technical skills being worked on as the need arises (see Stolz and Pill 2014, for an overview). The extent to which student questioning particular to each approach makes use of divergent questions stirring open-ended discussions among students (Pearson and Webb 2008) varies from one approach to another. Questioning from the teacher in relation with T-DLM, remains minimal, teammates' feedback on prior game play acting as implicit divergent questioning (Harvey et al. 2016).

\section{Tactical-Decision Learning Model (T-DLM)}

\section{The Model in Short}

As mentioned earlier, the use of a tactical approach as framework, along with the contribution of a not only cognitive but also constructivist perspective and their work on tactical knowledge in team sports, has led researchers, in the context of school physical education, to put forward T-DLM. The model focuses on the exploration by students of the various possibilities of game-play and on the construction of adequate responses in small-sided games (Figure 2). 
Figure 2. A Model for Students' Construction of Knowledge in Team Sports (TDLM)

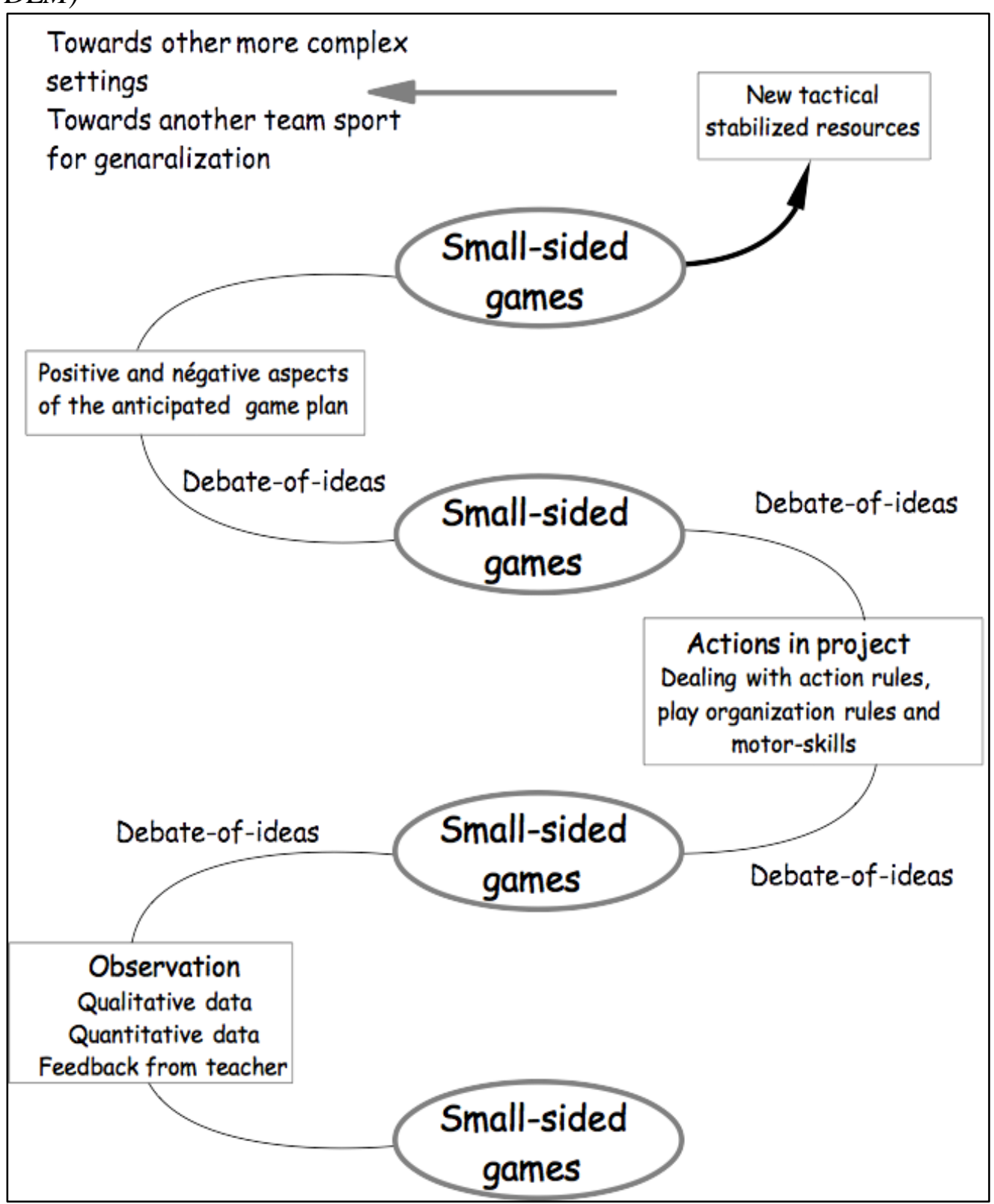

Figure 2 illustrates various steps which should enhance students' construction of tactical knowledge and the development of their decision-making skills. At the very onset of the learning sequence, students are put into action in some form of adaptation of the game, usually small-sided contests. For instance, a lesser number of players should simplify the configurations of play. However, the use of smaller play areas calls for some caution and should be balanced against the number of players involved since this may cause an increase in the time constraints, a limiting factor for decision making (Gréhaigne and Godbout 1998b). After appropriate student observation, feedback from teammate observers, and at times from the teacher, will complement the intrinsic feedback experienced by each player. A 
debate of ideas follows in which each team puts together a first action project. This is then tried out in play. From one game-play session to another, students take turns as observers while remaining fully part of the collective discussion and decisions. Following observation, the team's success in implementing the game plan is assessed and proposals for a revision can be made. Should the need for working on technical skill(s) arise, students may elect to include technical pauses in their action project.

After a new exposure to play, students may perceive the emergence of constants for various aspects of the game. This in turn can lead to the development of a new action project with the introduction of connections between action rules, play organization rules (Gréhaigne and Godbout 1995), and required skills on the one hand, and the constants that have just been identified on the other. For instance, in soccer, students may notice that in the last games, their number of shots on goal has increased and stays higher, without a resulting increase in the number of successful shots (points). Given that, they can concentrate either on improving their kicking or shooting accuracy or on getting closer to the goal. After testing its new action project during additional game play (with concurrent student observation), each team may use the results of their teammate's observations to appreciate positive and negative aspects of their anticipated game plan. In doing so, players are progressively putting together tactical knowledge and refining their decision-making skills. However, students often need to acknowledge that their current solutions are not effective, which should bring them to re-conceptualize their answers and willingly engage in an effort to change their conceptual understanding of game and team play. The teacher may also reduce tasks constraints in a number of ways by reducing the number of players on the court (or the pitch), inserting a joker (support player) in game play (Nadeau et al. 2017), or modifying the equipment (e.g., less pressure in the ball). Once stabilization appears to be taking place, more complex learning settings may be introduced and, eventually, players may be exposed to another team sport to initiate a generalization process.

Essential aspects of a cognitive and, moreover, constructivist approach, such as effective problem setting, the integration of students' past knowledge, experience with new learning and a student-centered pedagogy, are central in T-DLM. As illustrated in Figure 2, it evolves from an initial exposure to the pedagogical content to a state of stabilized knowledge of that content but such a process requires time. Students' understanding of tactical game-play accumulates gradually leading to new knowledge that enhances prior cognitive resources (Ennis 2007).

\section{Understanding the Internal Logic of Team Sports}

Within team sports, a large part of understanding is based on the fact that players are either defenders or attackers with respect to possession of the ball as well as configurations of play. In invasion games, the logic of the play has its source in this opposition relationship that generates dynamic movements from one target to the other (Deleplace 1966, 1979, Gréhaigne 1989, Gréhaigne et al. 2010a). 
The opposition relationship constitutes what is known as the rapport de forces. Gréhaigne et al. (1997) refer to "the antagonist links existing between several players or groups of players confronted by virtue of certain rules of a game that determine a pattern of interaction" (p. 516). Figure 3 illustrates the antagonist links in soccer.

Figure 3. The Antagonist Links in Soccer

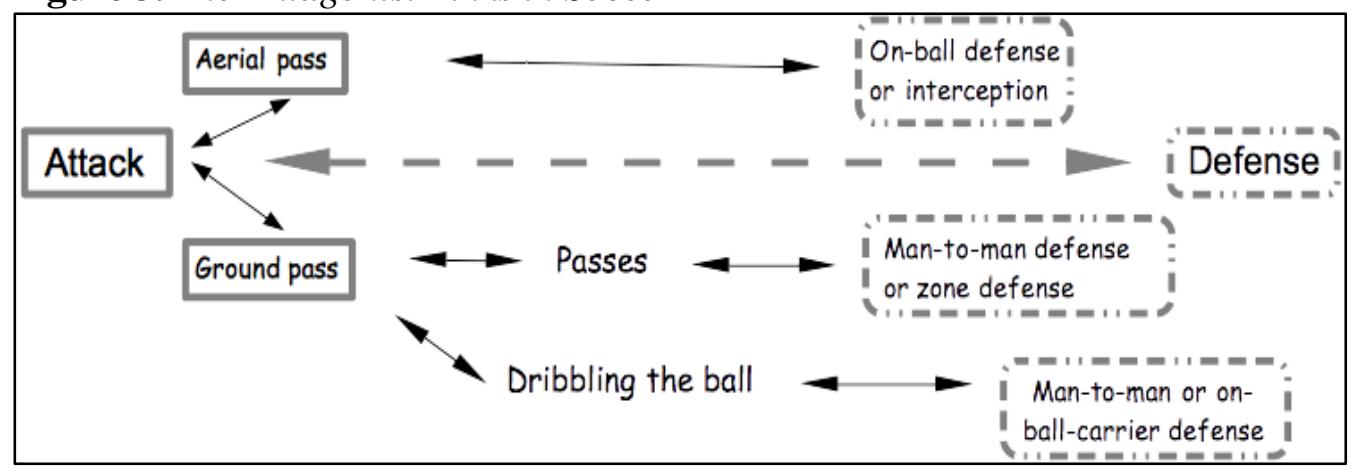

Gréhaigne et al. (1997, p. 501) wrote "The fundamental challenge in team sports could be stated as follows: in an opposition relationship while ensuring the defense of its own side, the team must coordinate its actions in order to recapture, conserve and move the ball so as to bring it into the scoring zone and score". The knowledge and the motor-skills that students need to learn are deeply connected with this conception of game-play. In this perspective, teachers or coaches should make provision for several-week long teaching sequences if true new resources are to be constructed by students because for many boys and girls who have participated in sport with little thought about the tactical nature of the game, a major restructuring or knowledge transformation is required to conceptualize games as tactical problems (Ennis 2007). Based on the findings of practical experimentation and empirical studies (Chang 2009, Nachon and Chang 2004, Zerai 2011), 10 to12-hour long teaching units appear to be the minimum necessary to see changes in tactical learning. Results from the Avalon project supported these findings and suggest that for tactical learning to occur, students need a minimal 10-hour long exposure to a student-centered approach (Gréhaigne et al. 2005a).

Figure 4 illustrates a model suitable for using with regards to students' challenges in game play (internal logic of team sports referred to above) and the ways students may proceed to solve them. 
Figure 4. Model to Analyze and Anticipate Game Play based on an Analysis of Configurations of Play in Soccer with Defense in Block at the Beginning of the Sequence

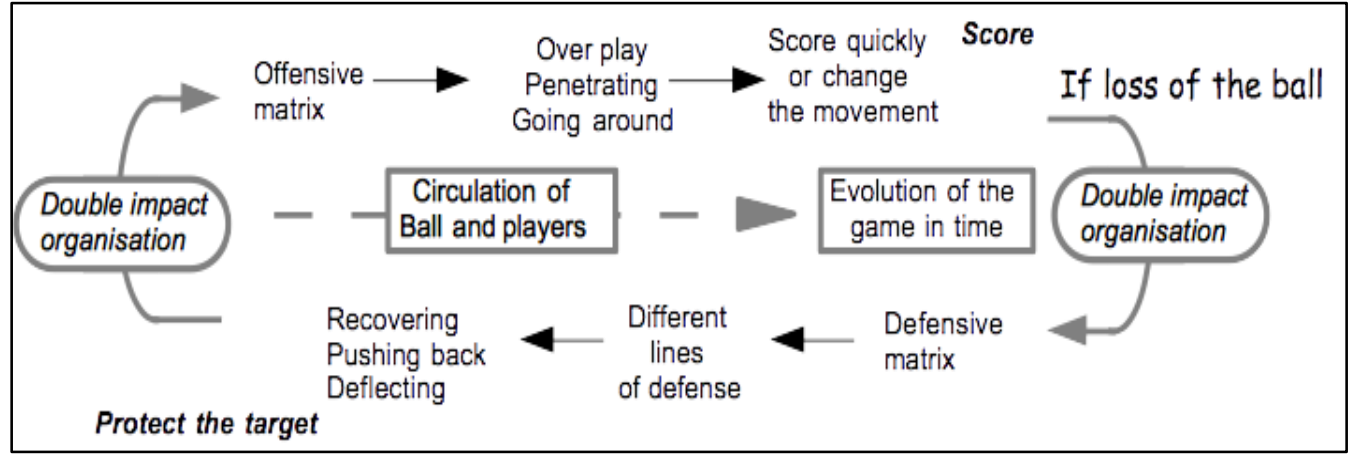

Source: Gréhaigne et al. 2013.

The model illustrates potential attack and defense tactical behaviors with a defense in block (the most common situation in soccer). These represent the contribution of the subject-matter knowledge related to the reference socialpractice (the fully developed sport). The notion of double-impact organization becomes very important for it emphasizes the immediacy of switching from attackers to defenders in case of ball loss; for their part, after regaining possession of the ball, defenders become attackers. Consequently, to ensure the continuity of game play there is always a part of defense in the attack and a part of attack in the defense (Gréhaigne et al. 1997). In other words, each player's basic challenge is cooperating with teammates in order to more effectively confront opponents either while attacking (keeping defense in mind) or while defending (keeping ready to counterattack) (Gréhaigne et al. 2001).

At the center of the figure, one finds critical elements of tactical knowledge for players. Awareness of the position and circulation of the ball and that of players (in term of configurations of play), awareness of game play (with regard to its evolution time-wise), and recognition of prototypic configurations of play (with their likely evolution) are key elements for players' understanding of the way game play unfolds. Although not a component of the logic of the sport in itself, students' knowledge of their team's competency network (particular strengths and weaknesses of each teammate) will also play its part in strategic and/or tactical decision making (Gréhaigne et al. 1999, Gréhaigne et al. 2004). Having the teacher draw students' attention on the various elements included in the model illustrated in Figure 4 provides, for the benefit of student-players, both affordances (facilitating information-tactics coupling) and external attentional focus (providing opportunities for successful action) (Chow 2013).

For the students to make it their own implies that the model be discussed and that students make it work. In so doing, they become aware of its areas of application and validity, rectify it or render it more complex through interactions by considering and testing consequences of new game experiments. Offensive and defensive matrices of play may be considered as advance organizers, each a frame of reference that helps players organize perceived information in view of responding more efficiently to problems brought about during game play 
(Gréhaigne and Godbout 2014, p. 108). Rather than a series of isolated skills practiced in close-task contexts, matrices of play require cognitive analysis and domain-specific strategic thinking that assist students in considering the evolution of game play as a coherent endeavor. In relation with the notion of matrices of play, Ennis (2007) stated "certainly, implementing Gréhaigne's play configurations and modeling based on defensive and offensive matrices brings a welcome focus on cognitive conceptualization as a prerequisite to tactical success" (p. 21).

\section{Student Content Knowledge in Team Sport}

Concerning student learning, it is generally agreed that proper scaffolding of student game-play knowledge can improve its use (Zerai et al. 2013). Depending upon the teacher's approach to leaning, student knowledge may vary significantly. Table 1 gives examples of content knowledge related to a technical approach (on the left-hand side of the Table) as opposed to a tactical approach (on the right-hand side). A technical approach considers the technical requirements of the game as the central focus of what and how things are going to be taught. A typical lesson in this type of approach is made up of three phases: (1) a warm-up; (2) the learning of skills; and (3) a short game at the end the lesson. The overall process involves (a) reproducing predetermined forms of gestures (technique, skill) and strategies, (b) comparing expected models and actual productions, and (c) correcting wrong answers by feedbacks and memorizing through repetition.

Table 1. Facets of Content Knowledge in a Technical vs a Tactical Approach

\begin{tabular}{|l|l|}
\hline $\begin{array}{l}\text { Technical approach } \\
\text { Students repeating } \\
\text { individual or collective patterns }\end{array}$ & $\begin{array}{l}\text { Tactical approach } \\
\text { Students making } \\
\text { individual or collective choices }\end{array}$ \\
\hline $\begin{array}{l}\text { Reconstructing skills in other situations or } \\
\text { team sports }\end{array}$ & $\begin{array}{l}\text { Applying what has been decided by the } \\
\text { team }\end{array}$ \\
\hline $\begin{array}{l}\text { In different sequences of play, increasing } \\
\text { the mastery of execution; }\end{array}$ & $\begin{array}{l}\text { Constructing tactics and techniques in a } \\
\text { situated context with opposition } \\
\text { relationships }\end{array}$ \\
\hline Practicing ready-made individual tactics & $\begin{array}{l}\text { Reading and interpreting game play with } \\
\text { tactics as a frame of reference }\end{array}$ \\
\hline Memorizing schemata of play & $\begin{array}{l}\text { Anticipating the sequences of events, } \\
\text { planning plausible responses }\end{array}$ \\
\hline
\end{tabular}

By contrast, in a tactical approach the emphasis is on the tactical aspects of the game in relation to modified game situations (e.g., 3 vs 3, 4 vs 4 ). At the beginning of a lesson, the teacher sets up different learning situations presenting a tactical problem to the students. In this approach, offensive aspects of the game will be emphasized. The teacher guides the students in this process by helping them to get organized, read game configurations and decide on appropriate responses. The teacher then helps students regulate their learning. The overall process involves, (a) producing actively adapted solutions, (b) exploring action strategies, and (c) developing reflective practices connected with opposition 
relationships in game plays. Behind the idea of students constructing conscious knowledge is the hypothesis that one can better use it and make better utilization of one's available resources.

\section{The Teaching/Understanding/Learning Triad}

Once the notions of student-centered approach and of tactical learning in team sports have been integrated, student understanding becomes an implicit, if not explicit corollary. In a student-centered teaching/learning process, understanding is a necessary cognitive catalyst. For that matter, any teaching approach, whether teacher-centered or student-centered, that aims at making students understand the reason for a given tactical or technical solution is cognitive.

The constructive perspective of tactical learning goes beyond and gives students the opportunity and responsibility to build their knowledge under the facilitating and learned guidance of their teacher. The left-hand side of Figure 5 illustrates the distinctions that have been used in the teaching/learning-related literature in relation with the notion of understanding. Bunker and Thorpe (1982) launched their now famous Teaching for Understanding, possibly taking learning for granted. Chandler (1996) wrote "TGFU is really a misnomer. As an approach it is student- and game-centered rather than teacher- and teaching centered. It would be better described as UFL-Understanding for Learning. We have too often seen teaching and learning as being thought of as synonymous or as having a direct cause and effect relationship" ( $\mathrm{p}, 51)$. Although expressed differently, the US National Research Council (NRC) (2000) shared similar thoughts when using the phrase learning with understanding (p. 8). Unaware, at the time, of these viewpoints, Gréhaigne et al. (2009) elected to designate the student constructivistlearning experience as learning through understanding. Despite subtle distinctions, viewpoints expressed by Chandler, NRC, and Gréhaigne et al. are the same: far from being an end in itself, understanding is but a step toward learning

Figure 5. Two Perspectives of the Teaching/Understanding/Learning Relationship

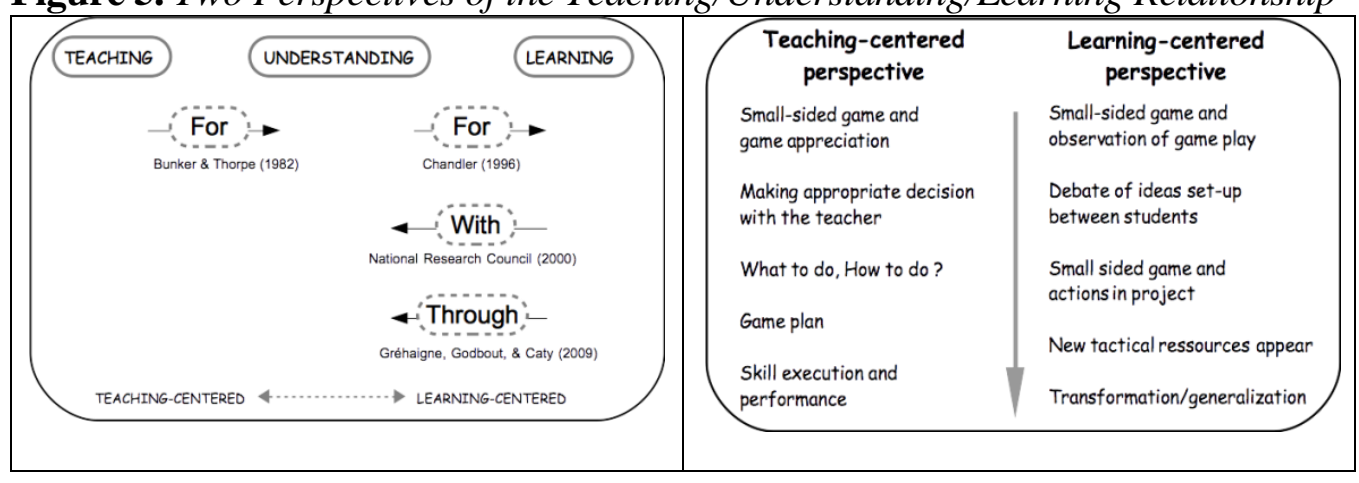

Also illustrated in Figure 5, in the right-hand side box, are the parts devoted to the teaching-centered perspective (left hand side) and to the learning-centered perspective (right hand side) in a teaching/learning system focused on both understanding and learning. With a teaching-centered perspective, the teacher or 
coach carefully assesses each step undertaken before and, if necessary, manipulates tasks constraints (Chow 2013, Tan et al. 2012) to further challenge learners. This is a crucial point for teachers or coaches; they must first identify the most important performance aspect that a student or a team needs to work on at any specific stage of their development and then adapt game rules accordingly. With a learningcentered perspective, at the end of the process with debates-of-ideas and a significant amount of practice, transformations imply not only the appearance of new answers to a given problem (answers in terms of improved motor skills or tactical behaviors) but also a stabilization of these answers for the student.

For new answers to be recognized as stabilized in game-play, they must meet three criteria: (a) regularity (reduction in the range of the answers and a stability of performance over successive trials); (b) durability (retention over an extended period of time), and (c) generalization (recognition of a similarity between several situations and the subsequent utilization and reorganization of previously learned action rules) (Gréhaigne and Godbout 1998b). The students' and teacher's engagement promote knowledge construction and transformation with a deepening understanding that remains essential for student engagement now and for a lifetime.

\section{A Comment about Students' Motor Skills}

A recurring comment on T-DLM is the little place it apparently leaves for students' motor-skill development. The model, like many other GBAs, has been developed in a student-centered perspective to enhance tactical learning. This was not developed for motor skills to be ignored. By the time students are exposed to team-sport learning in school, students are no longer novices with regard to motor ability, although their level may vary depending on individual past experiences. Modalities of student grouping for play sessions should help in this regard. One should also keep in mind the constructivist nature of T-DLM, meaning that through play sessions combined with concurrent student observation and following debates, students will become aware that the solution(s) to some observed problems reside(s) in taking technical pauses in their pursuit of tactical improvement. The model illustrated earlier in Figure 2 makes provision for such a possibility (see Actions in project box on the right-hand side of the figure). Most of the time, problems related to ball handling (dribbling, throwing, catching or receiving passes) will be reflected in the number of lost balls recorded by student observers (Gréhaigne and Godbout 1998a). Acting as a facilitator, the teacher may at times draw students' attention on the persistence of techniques-related game-play difficulties, suggesting possible remedies.

\section{Analyzing Game Play}

Team sports involving several teammates and opponents, they likely represent the most nonlinear subject-matter in the PE curriculum. While performing, each player has to deal with several teammates and take into account several opponents. 
Moreover, invasion team sports bring in an additional challenge for players, forcing them to move back and forth across an offensive and a defensive territory, attackers becoming defenders, and defenders becoming attackers. Collaborative and opposition interactions between players, in relation with the position of the ball (or the puck) and the target, create an endless variety of temporary player distributions on the playing area. With regard to the modelling of such distributions, one may consider the notions of effective (occupied) play-space (EP-S) and configuration of play.

\section{Effective Play-Space and Configurations of Play: Reference Tools for Students' Analysis}

With respect to invasion games, Mérand (1977) has developed the notion of EP-S, which is defined as the polygonal area that one obtains by drawing a line that links all involved players located at the periphery of the play at a given instant (Gréhaigne et al. 2005a, Gréhaigne et al. 2010b). At a given moment during game play, the EP-S, as a geometric figure, may be located anywhere on the play area with respect to the direction of attack: in the defensive zone, at the center of the play area, in the offensive zone. One may also choose to consider separately the distribution of both teams, thus creating an offensive EP-S and a defensive EP-S. The particular positioning of all players with respect to the ball is called the "configuration of play". Finally, the particular location of the ball inside the EP-S will be designated as being at the rear, in the middle, or at the front of EP-S.

Problems with analysis of performance in team sports in a context of smallsided games are those related to the assessment of any complex system, that is (a) the intervening elements are not only numerous but also interacting, (b) the opposition relationship plays an important role and it may vary in different opposition situations or even during one given situation and (c) the members of a given team are interdependent. Analyses of game-play may focus on the evolution of game play with respect to players' location, direction of movements and speed of movement, given momentary configurations of play (Gréhaigne and Godbout 2012, Mérand 1977). Consequently, efficiency during game-play has nothing to do with a series of dissociated behaviors. It relies on action rules and playorganization rules (Gréhaigne and Godbout 1995) that regulate strategic and tactical choices. It also relies, as we have seen earlier, on each player's knowledge of the competency network that prevails in his/her team and in the opposing team. The existence of the rules mentioned above appears to be confirmed by the fact that the students can adapt to many configurations of play and, eventually, state the rule or rules on which problem solving was based.

Coming back to play efficiency, one might say that tactical efficiency is the capacity to produce many tactical behaviors in response to infinite new configurations of play. Most of the time during the game, players can foresee only probabilities of evolution for the attack and defense configurations. Nevertheless, in these configurations of play, it is possible to extract configurations of play often used by players. Gréhaigne and his collaborators have called these configurations 
prototypical configurations in the sense that they represent an original model, archetype of a model that reproduces itself on a more or less regular basis in different team sports (Gréhaigne et al. 2010b, see also Nadeau et al. 2017, 31, for a discussion on attractor state and attractive configurations of play).

Figure 6 presents a few examples of prototypical configurations of play that allow students to develop the ability to make appropriate decisions and undertake actions accordingly. A game rarely rests upon the simple application of tactical combinations learned previously during training, hence the importance of tactical knowledge at a player's disposal in order to analyze and solve game-play problems more rapidly and efficiently (Gréhaigne 2007). The teacher's and students' challenge is for the latter to (a) come to grasp the notions of configuration of play and prototypical configurations of play, (b) become aware of the recurrence of given prototypical configurations of play, (c) recognize them when they occur during game play, and (d) strategically act according to action rules previously agreed upon or tactically react to an unexpected evolution of the configuration of play.

For the sake of our illustration, player-drawing sizes are enlarged, with respect to the dimension of the play area. In each figure, the drawing of the play area serves the purpose of a background whereas the drawing of the players represents an abstraction of a configuration of play. The same principle will apply in Figures 7 and 8 .

Figure 6. Six Different Prototypical Configurations of Play for the Students to Learn or to Remember

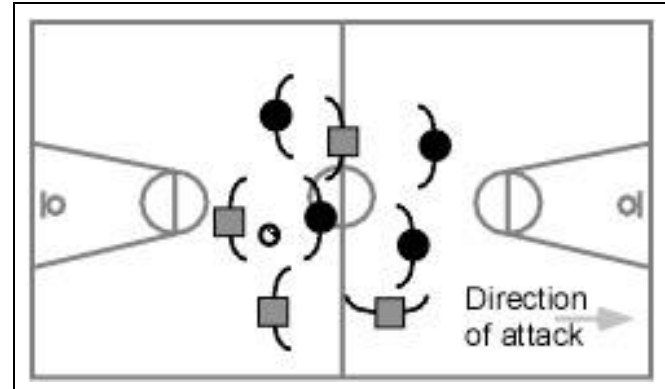

a. Attack with Ball at the Rear of EP-S. Defense is Retreating

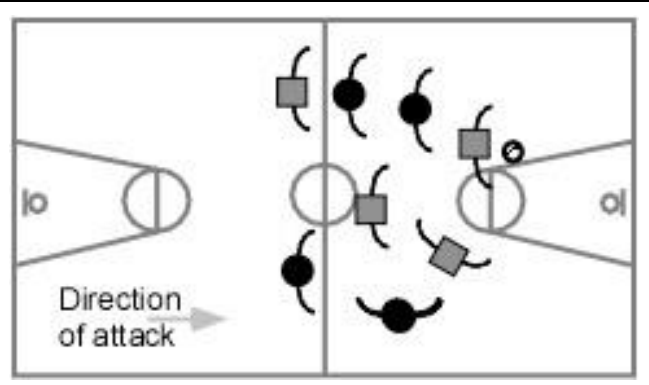

b. Attack with Ball at the Front of EPS. Defense is in Pursuit

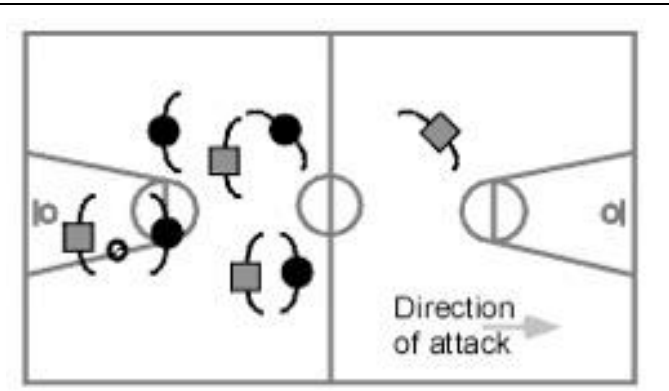

c. Counterattack Configuration

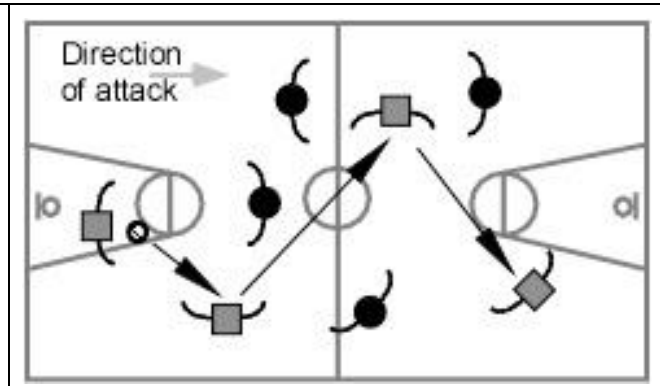

d. Play in Movement: Passes without Dribble (One-Touch Passing) 


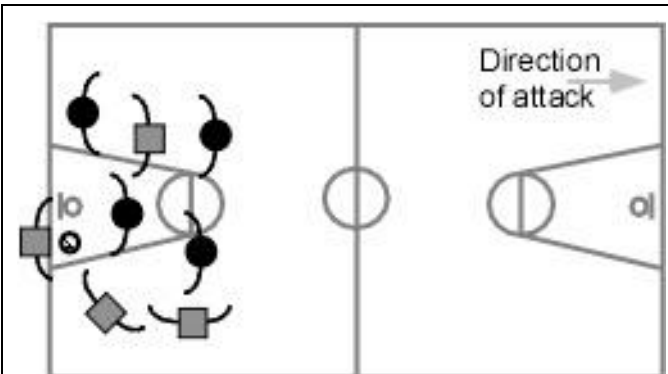

e. Restarting the Game with Beginners and Effective (Occupied) Play-Space

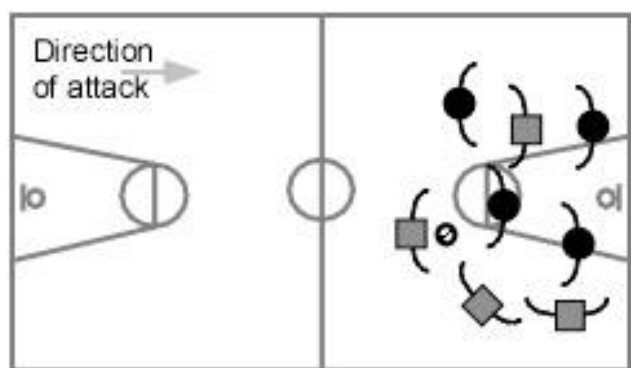

f. Attack of Position (Besieging)

Configurations of play may be interpreted from a dynamic point of view, considering first a temporary static look at a moment T0, as illustrated in Figure 7a below and then its look at moment $\mathrm{T}+1$ when four players have started moving. Besides location of the ball and the players at a given instant, awareness of speed and direction of movements is a powerful assistance for anticipation and decision making.

Figure 7. Illustration of Dynamic States in Configurations of Play

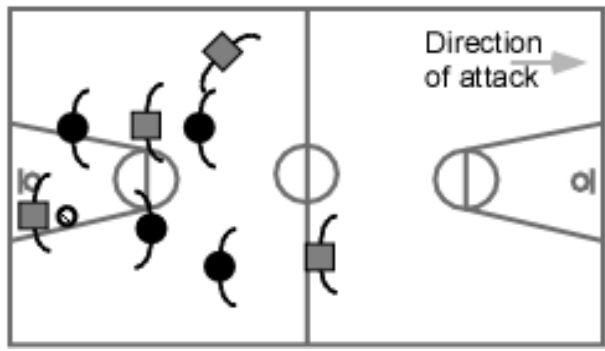

a. Dynamic State at T0

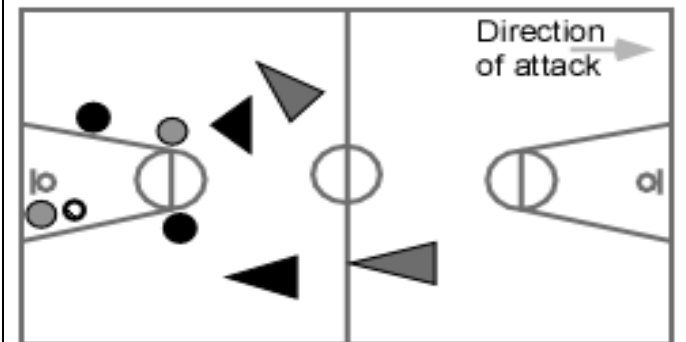

b. Dynamic State at $\mathrm{T}+1$

We have mentioned earlier that EP-S, although considering all players involved in the action, may be viewed as being composed of two distinct geometrical figures, the offensive EP-S and the defensive EP-S, as illustrated in Figure 8a and b. This distinction may help students better appreciate their respective positioning, particularly in a man-to-man defensive strategy.

Figure 8. Effective (Occupied) Play-Spaces with Respect to Offense and Defense

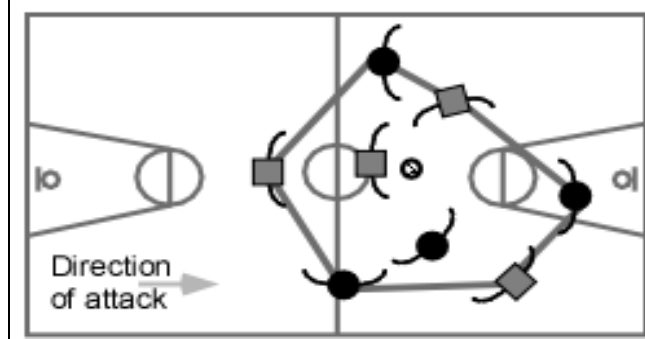

a. The Effective (Occupied) PlaySpace

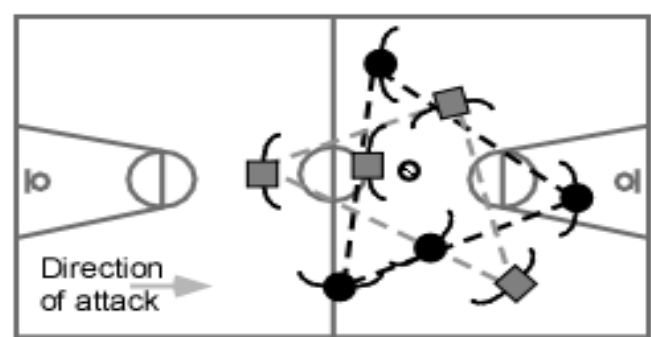

b. Offensive Effective Play-Space and Defensive Effective Play-Space 
Drawing students' attention on the size of EP-Ss may also enhance understanding of action rules (for instance, moving away from the opponents, in the intervals, or behind the opponents (Gréhaigne and Godbout 1995). Awareness of EP-S expansion (player dispersion) and contraction (player concentration) (Gréhaigne et al. 2010a) will help students understand that the closer team members aggregate, the harder for them it is to create passing opportunities and the easier it gets for opponents to intercept passes. Inversely, the more players disperse, expanding the EP-S, the more chances they have to get passes and move the ball rapidly. Action projects that favor dispersion will often result in having students include, in the project, practice sessions with regard to passing and receiving.

Observation tools illustrated in Figures 6, 7, and 8 make it possible to describe the dynamics of game-play and better understand, at a given moment, how players are moving. Everyone has a position but this position is changing because all players have a different instant speed. Thus, the evolution of the dynamic system can only be modeled by designing a discontinuous evolution in time. It seems that linking five criteria (EP-S field location; ball position and circulation; offensive effective play-space and defensive effective play-space positions; defense in block or in pursuit) provides an immediate representation of the opposition relationship (Gréhaigne et al. 2005a).

\section{Prototypical Configurations of Play and Action Rules}

Gréhaigne and Godbout (1995) define action rules as conditions to be enforced and elements to be taken into account if one wants to insure efficient action (p. 496). Such rules are basic to tactical knowledge about the game and their use, whether isolated or in connection with other rules, provides an answer to a given problem. Play organization rules (Gréhaigne and Godbout 1995) cover a certain number of themes related to:

- the logic of the activity (adopting a given system of play, taking into account the opposition relationships);

- the dimensions of the play area;

- the distribution of players on the field (assigning an optimal position on the field for each player);

- a differentiation of roles (assigning particular roles and tasks within the team).

These rules also cover a few simple organization principles which may facilitate the elaboration of a strategy (Gréhaigne et al. 2005a, b). We present below examples of action and play organization rules (see Figures 9 and 10) in connection with the state of the opposition relationship, the location of the ball, and the effective play-space. We shall consider that student, after having been exposed to situations illustrated below, have truly learned if, faced with a problem which is new but compatible with the resources at their disposal, they have 
transformed their initial behavior and have identified and verbalized the action and/or play organization rules that made their success possible. When mentioning resources at the students' disposal, we mean tactical, motor and physical inner resources that are inherent and/or previously learned.

Situations illustrated in Figures 9 and 10 represent again abstractions of configurations of play. For the sake of generalization to different invasion teamsport (e.g., soccer, basketball, ice hockey, handball), particular features of play areas have been deleted. Direction of attack is always from left to right in both figures. In both figures, attackers are represented by grey squares and defenders by black circles. A possible adaptation of game play rules might be to have sizereduced goals without a goalkeeper; this would motivate attackers to move closer to take a shot at goal, putting even more focus on the application of appropriate action rules. The ball is always directly in front of the attacker in possession.

Figure 9. Different Configurations with Locations of the Ball in the Middle of EP-S

\begin{tabular}{|c|c|c|c|}
\hline $\begin{array}{l}\text { Attack (grey } \\
\text { squares) } \\
\text { EP-S location ... }\end{array}$ & $\begin{array}{l}\text { Location of the } \\
\text { attack: ball is in } \\
\text { EP-S in balance }\end{array}$ & $\begin{array}{l}\text { all in the } \\
\text { the middle of } \\
\text { l confrontation }\end{array}$ & $\begin{array}{l}\text { Offensive actions and/or } \\
\text { play organization rules } \\
\text { to be constructed }\end{array}$ \\
\hline $\begin{array}{l}\text { a. In the } \\
\text { attackers' } \\
\text { offensive area }\end{array}$ & & $\bullet \bullet \bullet$ & $\begin{array}{l}\text { - I pass the ball to a forward } \\
\text { partner. } \\
\text { - I let the ball move through a } \\
\text { one touch play. } \\
\text { - I try to shoot at goal. }\end{array}$ \\
\hline $\begin{array}{l}\text { b. In the middle } \\
\text { of the field }\end{array}$ & - $\bullet$ & $\bullet$ & $\begin{array}{l}\text { - I pass the ball to a forward } \\
\text { partner. } \\
\text { - I try to keep the advance } \\
\text { taken. } \\
\text { - I dribble the ball in the } \\
\text { offensive area. }\end{array}$ \\
\hline $\begin{array}{l}\text { c. In the } \\
\text { attackers' } \\
\text { defensive area }\end{array}$ & $\stackrel{\bullet}{\bullet} \bullet_{\square}^{\bullet}$ & & $\begin{array}{l}\text { - I pass the ball to a forward } \\
\text { partner. } \\
\text { - I let the ball move through a } \\
\text { one touch play. } \\
\text { - I try to bring the ball ahead } \\
\text { of the EP-S. }\end{array}$ \\
\hline
\end{tabular}


Figure 10. Different Configurations with Defense in Pursuit

\begin{tabular}{|c|c|c|}
\hline $\begin{array}{l}\text { Defense (black } \\
\text { circles) } \\
\text { in pursuit } \\
\text { EP-S location ... }\end{array}$ & $\begin{array}{l}\text { Location of the ball in the } \\
\text { attack: ball is at the front of } \\
\text { EP-S }\end{array}$ & $\begin{array}{l}\text { Defensive actions and/or play } \\
\text { organization rules } \\
\text { to be constructed }\end{array}$ \\
\hline $\begin{array}{l}\text { a. In the } \\
\text { attackers' } \\
\text { offensive area }\end{array}$ & $\begin{array}{ll}\bullet & \bullet \\
0 & \square \\
0 & 0\end{array}$ & $\begin{array}{l}\text { - I try to prevent the shot on goal. } \\
\text { - I try to block the attacker in } \\
\text { order to force him/her off center. } \\
\text { - I delay as long as possible the } \\
\text { shot on goal or a decisive pass } \\
\text { from one of the two partners. }\end{array}$ \\
\hline $\begin{array}{l}\text { b. In the middle } \\
\text { of the field }\end{array}$ & \begin{tabular}{ll|l}
$\bullet$ & $\bullet$ \\
$\bullet$ & $\bullet$ &
\end{tabular} & $\begin{array}{l}\text { - I move back swiftly between the } \\
\text { ball and the target since there is } \\
\text { still room for defense. } \\
\text { - I put pressure on the attacker in } \\
\text { order to provoke a mistake or a } \\
\text { mishandling. }\end{array}$ \\
\hline $\begin{array}{l}\text { c. In the } \\
\text { attackers' } \\
\text { defensive area }\end{array}$ & $\begin{array}{l}\bullet \quad \bullet \\
\bullet \quad \square \circ \\
\square \bullet\end{array}$ & $\begin{array}{l}\text { - I move back between the ball } \\
\text { and the target since there is a long } \\
\text { distance to cover. } \\
\text { - I delay the decision and force } \\
\text { the attacker to make a wrong } \\
\text { choice due to precipitation. } \\
\text { - Stepping back /laying. }\end{array}$ \\
\hline
\end{tabular}

The configurations of play illustrated above, although momentary, are commonplace in 4 vs 4 games. They represent instant photos of game play, exposing, through their unfolding, the tactical organization agreed upon by the team (Gréhaigne et al. 2007).

\section{Conclusion}

Based on the evolution of pedagogical theoretical choices and practices in France over the last 50 years, PE teacher educators, practitioners, and researchers in the didactics of team sports have developed a student-centered teaching approach that favors situated learning and the use of small-sided games. Student understanding of action and play organization rules, through experimentation, student observation, and related student debates of ideas, is viewed as a necessary step toward learning. Throughout the learning process, students are challenged to collectively plan action projects, implement them in game play situations, and conclude as to their level of success or failure, going through several iterations of the process until stabilization of their acquired knowledge. This learning process unfolds under the teacher's learned and facilitating guidance. T-DLM, the underlying model discussed in this paper, enhances tactical learning, provided that the teaching/learning unit lasts a minimal number of 10-12 hours. 


\section{References}

Amade-Escot C (2000) The contribution of two research programs on teaching content: "Pedagogical Content Knowledge" \& "Didactics of Physical Education". Journal of Teaching Physical Education 20(1): 78-101.

Bouthier D (1984) Sports collectifs: contribution à l'analyse de l'activité et éléments pour une formation tactique essentielle. L'exemple du rugby. (Team sports: contribution to the analysis of activity and elements for an essential tactical education). Unpublished Master's Thesis. Paris, France: INSEP.

Bouthier D (1988) Les conditions cognitives de la formation d'actions sportives collectives. (Cognitive conditions for organizing actions in team sports). Unpublished Doctoral Dissertation. Paris, France: Université Paris V.

Bunker D, Thorpe R (1982) A model for the teaching of games in the secondary schools. The Bulletin of Physical Education 18(1): 5-8.

Chandler T (1996) Teaching games for understanding - Reflections and further questions. Journal of Physical Education, Recreation \& Dance 67(4): 49-51.

Chang C-W (2009) Langage, pensée et action: approche sémio-constructiviste des apprentissages du jeu en basket-ball chez l'élève de CM2 (5ième grade). (Language, thought and action: semio-constructivist approach to basketball game-play learning with $5^{\text {th }}$ grade pupils). Unpublished Doctoral Dissertation. Besançon, France: University of Franche-Comté.

Chow JY (2013) Nonlinear learning underpinning pedagogy: evidence, challenges, and implications. Quest 65(4): 469-484.

Deleplace R (1966) Le rugby. (Rugby Union). Paris: Colin-Bourrelier.

Deleplace R (1979) Rugby de mouvement - Rugby total. (Rugby in movement - Total rugby). Paris, France: Éducation Physique et Sport.

Deriaz D, Poussin B, Gréhaigne J-F (1998) Le débat d'idées. (The debate of ideas). Éducation Physique et Sport 273: 80-82.

Ennis CD (2007) Curricular coherence: a key to effective physical activity programs. In P Heikinaro-Johansson, R Telama, E McEvoy (eds.), AIESEP World Congress 2006 Proceedings: The Role of Physical Education in Promoting Physical Activity and Health, 10-25. Jyväskylä, Finland: Department of Sport Sciences, University of Jyvaskyla.

Frantz P (1975) Le football. (Soccer). Mulhouse, France: L'Alsace.

Gréhaigne J-F (1989) Football de mouvement. Vers une approche systémique du jeu. (Soccer in movement. Towards a systemic approach of the game). Unpublished Doctoral Dissertation. Dijon, France: Université de Bourgogne.

Gréhaigne J-F (ed.) (2007) Configurations du jeu, débat d'idées et apprentissage des sports collectifs. (Configurations of play, debate-of-ideas and learning of team sports). Besançon, France: Presses de l'Université de Franche-Comté.

Gréhaigne J-F, Guillon R (1991). Du bon usage des règles d'action. (Making good use of action rules). Échanges et Controverses 4: 43-66. Paris, France: APECC.

Gréhaigne J-F, Godbout P (1995) Tactical knowledge in team sports from a constructivist and perspective. Quest 47(4): 490-505.

Gréghaigne J-F, Godbout P (1998a) Formative assessment in a tactical approach context. Journal of Physical Education, Recreation \& Dance 69(1): 46-51.

Gréhaigne J-F, Godbout P (1998b) Observation, critical thinking and transformation: three key elements for a constructivist perspective of the learning process in team sports. In R Feingold, R Rees, G Barrette, L Fiorentino, S Virgilio, E Kowalski (eds.), Education for Life, 109-118. New-York, USA: Adelphi University. 
Gréhaigne J-F, Godbout P (2012) À propos de la dynamique du jeu ... en football et autres sports collectifs. (About the dynamics of game play... in soccer and other team sports). eJournal de la Recherche sur l' Intervention en Éducation Physique et Sport 26(Apr): 130-156.

Gréhaigne J-F, P Godbout (2014) Dynamic systems theory and team sport coaching. Quest 66(1): 96-116.

Gréhaigne J-F, Billard M, Guillon R, Roche J (1988) Vers une autre conception de l'enseignement des sports collectifs. (Towards another view of the teaching of team sports). In G Bui-Xuan (ed.), Méthodologie et Didactique de l'Éducation Physique et Sportive, 155-172. Clermont-Ferrand, France: AFRAPS.

Gréhaigne J-F, Godbout P, Bouthier D (1997) Performance assessment in team sport. Journal of Teaching in Physical Education 16(4): 500-516.

Gréhaigne J-F, Godbout P, Bouthier D (1999) The foundations of tactics and strategy in team sports. Journal of Teaching in Physical Education 18(2): 159-174.

Gréhaigne J-F, Godbout P, Bouthier D (2001) The teaching and learning of decision making in team sports. Quest 53(1): 59-76.

Gréhaigne J-F, Caty D, Marle P (2004) L'apport de la notion de configuration du jeu à la didactique des sports collectifs. (The contribution of the notion of configuration of play to the didactics of team sports). In G Carlier (ed.), Si l'on Parlait du Plaisir d'Enseigner l' Éducation Physique, 167-179). Montpellier, France: AFRAPS.

Gréhaigne J-F, Richard J-F, Griffin L (2005a) Teaching and learning team sports and games. New York, USA: Routledge Falmer.

Gréhaigne J-F, Wallian N, Godbout P (2005b) Tactical-decision learning model and student' practices. Physical Education \& Sport Pedagogy 10(3): 255-269.

Gréhaigne J-F, Caty D, Marle P (2007) Étude systématique de différentes configurations du jeu dans les jeux réduits. (Systematic study of various configurations of play in small-sided games). In J-F Gréhaigne (ed.), Configuration du Jeu. Débats d'Idées \& Apprentissage du Football et des Sports Collectifs, 43-60. Besançon, France: Presses de l'Université de Franche-Comté.

Gréhaigne J-F, Godbout P, Caty D (2009) Learning games through understanding: new jobs for students! International Journal of Physical Education 46(4): 30-38.

Gréhaigne J-F, Godbout P, Zerai Z (2010a) Using complex system analysis to model team ball sports. International Journal of Physical Education 47(4): 28-40.

Gréhaigne J-F, Caty D, Godbout P (2010b) Modelling ball circulation in invasion team sports: a way to promote learning games through understanding. Physical Education and Sport Pedagogy 15(3): 257-270.

Griffin L, Butler J (eds.) (2005) Teaching games for understanding: theory, research and practice. Champaign, IL: Human Kinetics.

Griffin LL, Mitchell SA, Oslin JL (1997) Teaching sport concepts and skills: a tactical games approach. Champaign, IL: Human Kinetics.

Harvey S, Cope E, Jones R (2016) Developing questioning in game-centered approaches. Journal of Physical Education, Recreation \& Dance 87(3): 28-35.

Harvey S, Jarrett K (2014) A review of the game-centered approaches to teaching and coaching literature since 2006. Physical Education and Sport Pedagogy 19(3): 278300 .

Light R (2004) Australian coaches' experiences of Game Sense: opportunities and challenges. Physical Education and Sport Pedagogy 9(2): 115-132.

Mahlo F (1965) Theoretische Probleme der taktischen: Ausbildung in den sportspielen. (Theoretical problem of tactics: training in sports games). Theorie und Praxis der Körperkultur 14(9): 809-816.

Mahlo F (1969) Acte tactique en jeu. (Tactical action in play). Paris, France: Vigot. 
Marsenach J, Druenne F (1974) Volley-ball. Mémento CPS FSGT. Paris, France: Armand Colin-Bourrelier.

Menaut A (1982) Contribution à une approche théorique des jeux sportifs collectifs (Contribution to a theoretical approach for team-sport games). Unpublished Doctoral Dissertation. Bordeaux, France: Université de Bordeaux 2.

Mérand R (1974) Maurice Baquet: rénovation de l'éducation physique et innovation pédagogique. (Maurice Baquet: renovation of physical education and pedagogical innovation). Revue Éducation Physique et Sports 127(May-Jun): 33-38.

Mérand R (1977) L'éducateur face à la haute performance. (The educator faced with high performance). Paris: Sport et Plein air.

Nachon M, Chang CW (2004) Interactions verbales entre les élèves et projet d'action en basket-ball en classe de troisième. (Student verbal interactions and action projects in basketball with high school students). eJournal de la Recherche sur l'Intervention en Éducation Physique et Sport 5: 15-36.

Nadeau L, Gréhaigne J-F, Godbout P (2017) Developing tactical knowledge with the help of support players: an illustration in ice hockey. International Journal of Physical Education 54(1): 22-33.

Pearson PJ, Webb P (2008) Developing effective questioning in Teaching Games for Understanding (TGfU). Paper Presented at the $1^{\text {st }}$ Asia Pacific Sport in Education Conference: Ngunyawaiendi Yerthoappendi Play to Educate, Adelaide.

Siedentop D (2002) Sport education: a retrospective. Journal of Teaching in Physical Education 21(4): 409-418.

Stolz S, Pill S (2014) Teaching games and sport for understanding: exploring and reconsidering its relevance in physical education. European Physical Education Review 20(1): 36-71.

Tan CWK, Chow J-Y, Davids K (2012) How does TGfU work? Examining the relationship between learning design in TGfU and a nonlinear pedagogy. Physical Education and Sport Pedagogy 17(4): 331-348.

Teodorescu L (1965) Principes pour l'étude de la tactique commune aux jeux sportifs collectifs. (Principles for to the study of common tactics in team sports). Revue de la Société d'Informations et d'Études Pédagogiques de l'Éducation Physique et Sportive 3: 29-40.

Teodorescu L (2013) Principes pour l' étude de la tactique commune aux jeux sportifs collectifs et leur corrélation avec la préparation tactique des équipes et des joueurs. (Principles for to the study of common tactics in team sports and their correlation with the tactical preparation of teams and players). eJournal de la Recherche sur l'Intervention en Éducation Physique et Sport, 28: 99-117.

US National Research Council (2000) How people learna: brain, mind, experience, and school: expanded edition. Washington, DC: The National Academies Press.

Vandevelde M (2007) Repères chronologiques sur le parcours professionnel et militant de Robert Mérand. (Chronological landmarks on Robert Mérand's professional and liberal career). Paris, France: Éditions Syllepse.

Zerai Z (2011) Apprentissage du handball chez les jeunes filles Tunisiennes et Françaises; apport de la verbalisation. (Learning in handball for French and Tunisian young girls: input of verbalization). Unpublished Doctoral Dissertation. Besançon, France: Université de Franche-Comté.

Zerai Z, Gréhaigne J-F, Godbout P (2013) Configurations of play in invasion team sports and learning by analogy. International Journal of Physical Education 50(1): 18-28. 